\title{
Do Individual Traits Associate with Ethical Judgment?
}

\author{
Shaheen Mansori ${ }^{1}$, Zabihollah Rezaee ${ }^{2}$, Saeid Homayoun ${ }^{3}$ \& Ali Taebi Noghondari ${ }^{4}$ \\ ${ }^{1}$ Associate Professor in Marketing, Faculty of Business Communication and Law, INTI International University, \\ Malaysia \\ ${ }^{2}$ Thompson-Hill Chair of Excellence \& Professor of Accountancy, Fogelman College of Business and Economics, \\ The University of Memphis, USA \\ ${ }^{3}$ Assistant Professor in Accounting, Department of Business and Economic Studies, Faculty of Education and \\ Economics, University of Gävle, Sweden \\ ${ }^{4}$ Putra Business School, Universiti Putra Malaysia, Malaysia \\ Correspondence: Saeid Homayoun, PhD, Department of Business and Economic Studies, Faculty of Education \\ and Economics, University of Gävle, Sweden, Kungsbäcksvägen 47, 80176 Gävle, Sweden. Tel: 46-26-648-500. \\ E-mail: sadhon@hig.se
}

Received: May 12, 2015

Accepted: June 16, 2015 Online Published: August 28, 2015

doi:10.5539/jms.v5n3p85

URL: http://dx.doi.org/10.5539/jms.v5n3p85

\begin{abstract}
Existence and persistence of financial scandals and crises has invigorated more interest in ethical judgment and behavior of policymakers, regulators, and executives throughout the world. These events have weak ened the trust among the public and investors' confidence towards the financial markets globally and their financial reports. In this paper, we examined the role of individual traits in ethical judgment process and develop a model of assessing the effectiveness of the identified individual traits. We conducted a survey among 280 undergraduate business students at five private and public universities in Malaysia. We identified that gender identification, religiosity, ethnicity, and basic individual values are important considerations in making ethical judgment. These results suggested that personal traits and psychological factors play an important role in the ethical judgment process.
\end{abstract}

Keywords: ethics, moral judgment, religiosity, ethnicity, femininity, masculinity, individual's basic values

\section{Introduction}

Reported financial scandals by high-profile companies (Enron, WorldCom, Global Crossing, Qwest, Parmalat, Satyam, and Olympus) and associated global ethical debacles during the past two decades have weakenedthe trust and the public and investors' confidence in financial markets. This is probably due to the major corporate scandals that started coming to light in the late 1990s and the first decade of the 21 st century. It is evident that unethical behavior on the part of corporations can lead to financial failure and also profound impact on its stakeholders and stability of society as a whole (Giacalone \& Jurkiewicz, 2003). Consequently, a high ethical standard is expected of all who enter this profession to confirm their integrity is not being jeopardized. When there are cases of corporate collapses, normally there are general perceptions which indicate that fraud was, in part, made possible by auditors who did not adhere to a high standard of truth and integrity (Satava et al., 2006). Therefore, in the name of public benefit, regulators across the globe have stepped up their scrutiny of the accounting profession and have released federal laws (such as Sarbanes-Oxley Act (2002) in the US and Malaysian Code of Corporate Governance (2007) in Malaysia) and auditing standards (e.g., SAS 99). The wave of financial scandals, financial crises, and related regulatory responses and best practices has galvanized an interest in ethics and a demand for compliance training programs and ethical judgment (Brockett \& Rezaee, 2012).

The International Accounting Education Standards Board (IAESB), an independent standard setting board within the IFAC has come out with a Framework for International Education Pronouncements in October 2003. Recently, in October 2008, the IAESB has updated the framework and released a standard namely, "International Education Standard (IES) 8, Competence Requirements for Audit Professionals". The IES 8 outlines the skills, training, professional values and attitudes necessary for auditors to perform competently and applies to all audit professionals. The IFAC Education Committee (1998) defines "competency" as "the ability to perform the tasks and roles expected of a professional accountant, both newly qualified and experienced, to the standard expected by 
employers and the general public". The auditors are capable when they acquire the attributes that enable them to perform their roles competently. The competence attributes are knowledge, skills, professional values, ethics and attitudes. From the literature, various empirical studies have been done on some of these attributes in audit judgement performance researches. Chang (1998) found that the theory of planned behaviour is better than the theory of reasoned action in predicting unethical behaviour. According to him, unethical behaviour requires substantial resources and opportunities for successful performance. Therefore, he suggests using the theory of planned behaviour in unethical behaviour research, since it includes perceived behavioural control, which involves opportunity and resources. Buchan (2005) included moral sensitivity and ethical "climate as organisational factor," parallel to the main constructs of the theory of planned behaviour. Passow et al. (2006) included moral obligation to the theory of planned behaviour model.

Interest in ethical attitudes of business students who are likely to be future business leaders is on the increase (Borkowski \& Ugras, 1992; Etzioni, 2002; Jennings, 2004). Ethics is defined as moral principles pertaining to what is right and wrong and virtuous behaviour which are related to values, and standards of conduct (Brockett $\&$ Rezaee, 2012). Where else, business ethics is related to a specialized aspect of ethics which promotes the use of appropriate professional judgment and being accountable for ethical decisions and actions (Brockett \& Rezaee, 2012). Crane (2004) found that business students want to be taught skills and tools to help manage difficult and problematic ethical situations. Studies by the Institute of Business Ethics (IBE) concluded that conducting business with ethical responsibility and integrity is not only the right thing to do but also good for the bottom line (Ugoji, Dando, \& Moir, 2007). Prior research had addressed the factors that might affect ethical/unethical behaviour (Baumhart, 1961; Cardy \& Selvarajan, 2006; Ian \& Kea., 2007; Lindfelt \& To"rnroos, 2006) and identified moral norms and personal traits as main factors that influence business ethics attitude in different situation and across countries (Moore \& Radloff, 1996; Sims \& Gegez, 2004; Small, 1992). However, the results of the current research are varied and still there are many aspects of this issue that remained unknown to the managers and academicians. Therefore, to address this phenomenon, the primary aim of this study is to develop a model that can assess the effectiveness of moral norms and personal traits in making ethical decisions.

The finding of this study may interest the decision makers and academicians as: 1) most of the current studies had focused on demographical factors (for example, age, race, gender) rather than the behavioural aspect of an individual which is better predictor and 2) the findings may provide suggestions for the managers pertaining to some new factors that should be considered during recruitment and selection of key personals in the companies. This research enriches the evidence on individual characteristics components in one study under Malaysian setting. Also this research highlights important areas for improving training \& development to supply valuable information towards the improvement of existing education curriculum in Malaysia.

\section{Literature Review}

\subsection{Moral Norms and Personal Traits}

Moral norm is individual commitment or characteristics to execute or reject a particular behavior (Beck \& Ajzen, 1991). Rejection or acceptance of any particular behavior can be influenced by the individual norms and values which are depending on whether the particular action is morally right or wrong (Ajzen, 2002). According to Ahmad (2000), moral obligation can be defined as "the duty or obligation that is sanctioned by one's conscience as right". Many studies had suggested that in order to have better perspective of human behavior, research should study the role of moral obligation besides other external social pressure in individuals' behaviors (Schwartz \& Tessler, 1972). Moral obligation can play a significant role in determining behaviors which are socially accepted (Beck \& Ajzen, 1991) or in situation where consideration based on morality is needed (Conner \& Armitage, 1998).

Some studies had found that moral norm is likely to be an significant antecedent of intention which is accordance with theory of planned behavior constructs (for example, Conner \& Armitage, 1998). However, another group of studies had shown that the perceived moral obligation has a weak relationship with intention, unless there is an opportunity for norm-relevant behavior (Kallgren, Reno, \& Cialdini, 2000). In addition to these findings, there are studies which had not found any significant relationship between moral sensitivity and ethical behavior intention. Due to these inconsistencies, many research studies had suggested that to understand this phenomenon, new studies should include a number of variables such as personality, religiosity, social interactions, life events, and opportunity to engage in moral actions which may influence the formation of commitment to moral judgments (for example, Hart, 2005; Kurpis, Beqiri, \& Helgeson, 2008). 


\subsection{Theory of Planned Behavior}

Theory of Planned Behaviour (TPB) is robust in many settings in predicting a broader range of behaviours (Sheppard, Hartwick, \& Warshaw, 1988). TPB explicates that individuals' behaviour can be elucidated the behaviour performed based on their intention which in turn explains the purpose of their attitude toward the behaviour and their subjective norm. According to TPB, behaviour can be explained by intention which is a cognitive representation of a person's willingness to perform a given action, and considered as the immediate antecedent of behaviour. This theory had been applied and validated in numerous studies (for example see Conner \& Armitage, 1998; Ajzen, 1991). Researches in ethics had also employed TPB (Ajzen, 2002) as the core of their studies to enlighten the relationship between the variables engage in ethical behaviour decisions. Chang (1998) applied Theory of Planned Behaviour (TPB) in unethical decision making. According to Beck and Ajzen (1991), to explain and predict cheating behaviour at colleges, TPB had also been used and proven effective (Passow et al., 2006). Bobek and Hatfield (2003) had used TPB and added moral obligation to study tax compliance behaviour of the participants. Their studies had shown that TPB can clearly explain tax compliance behaviour.

\subsection{Moral Judgment}

"Understanding what determines whether something is good or bad, right or wrong" is related to ethics which is a part of moral philosophy (Lewis \& Unerman, 1999). For decades many research had attempted to discover the main reasons behind ethical/unethical behavior of businessmen in different situations and contexts. Overall findings had revealed that moral judgment can be an important predictor for ethical judgments (Barnett, Bass, \& Brown, 1996; Barnett, Bass, Brown, \& Hebert, 1998; Douglas, Davidson, \& Schwartz, 2001).

Moral judgment has been operationalized by conducting several different approaches. However, usually many researches had studied moral judgment based on four different aspects; Universalism, Relativism, Moral equity and Contractualism. Reidenbach and Robin (1990) defined Contractualism as an implied contract of a notion which is acceptable as right versus wrong behavior that exists between business and society; Moral equity is individual perception of fairness and justice; Relativism is defined as individual's perception towards acceptable behavior that derives from the society/cultural perspective instead of his / her perspective (Reidenbach \& Robin, 1990). Moreover, universal approached had been described by a quote, "Do unto others as you would have them do unto everyone, including yourselves". Under this approach, individual would choose an action that would apply to all people under all situations. This approach considers the importance of individual's rights, which stem from individual freedom and autonomy.

A study by O'Fallon and Butterfield's (2005) showed that 185 researches in business ethics field tested the relationship of other factors with ethical judgment as a dependent variable. Their findings had revealed that researchers had used many individual traits, psychological characteristics (for example, cognitive moral development, need for cognition) and demographic characteristics (for example, gender, age, education) to explain and predict individual's moral judgments. However, since it covers a wide area of individual's characteristics which is difficult to study in a research, this study focuses on the relationships between religiosity, ethnicity, gender identification, human basic values "(two dimensions)" and moral judgment.

According to the analysis by Bailey et al. (2010), accounting studies involving ethical judgment and decision making, overwhelmingly deal with Component II of Rest's model, using the Defining Issues Test (DIT) to measure the judgment formation. The large number of studies in this section is due to the ease of administering the DIT. The literature on judgment formation is this extensive, and the reader is referred to Bailey et al. (2010).

\subsection{Religion/Religiosity}

Religion is defined as "a set of beliefs concerning the cause, nature, and purpose of the universe, especially when considered as the creation of a superhuman agency or agencies, usually involving power" (Oxford Advanced Learner's Dictionary, 2012). Religiosity is also defined as "the state of being religious or too religious", and religious is defined as "believing strongly in the existence of a god or gods" (Oxford Advanced Learner's Dictionary, 2005). The connection between religion and ethics seems to be obvious (Craft, 2013; Weaver \& Agle, 2002). Religion, based onits values, "norms" and beliefs often develop the foundation of mind set that adheres to what is considered right or wrong (Mansori, Sambasivan, \& Md-Sidin, 2015). These norms, values and beliefs are usually presented in religious holy books such as the Torah, Bible, or the Quran (Parboteeah, Hoegl, \& John, 2008).

Due to the sources of evidence of religion's role in the communities' socialization, researchers had attempted to study whether religion plays a significant role in influencing ethical attitude and behavior (Arslan, 2001; Lee, McCann, \& Ching, 2003; Vitell \& Paolillo, 2003; Walker, Smither, \& DeBode, 2012). However, despite the 
strong theoretical ties between ethics behavior and religiosity, not many studies had conducted empirical research in this field and the existing studies produced inconsistent conclusions (Weaver \& Agle, 2002). For an instant, some researches had shown there is no difference between religious and non-religious individuals in regard to unethical behaviors such as dishonesty and cheating (Hood, Spilka, Hunsberger, \& Gorsuch, 1996; Parboteeah et al., 2008). While other studies had found that the use of illegal substances and level of religiosity are negatively related (Khavari \& Harmon, 1982). Thus, to enhance the body of knowledge in this area, this study will test the following hypothesis:

H1: Religiosity is associated with ethical moral judgments as determined by contractualism, moral equity, relativism, and universalism.

\subsection{Gender Identification}

The role of gender differences in ethical decision making have been studied in some researches. Some findings have shown that men are more likely to accept and attempt unethical behavior compared to women who have significantly lower tendency to accept and attempt a doubtful ethical behavior (Beu, Buckley, \& Harvey, 2003; Mason \& Mudrack, 1996; Weeks, Moore, McKinney, \& Longenecker, 1999). However, there are findings that have shown no differences between female and male "in term making decision ethically" (Roxas \& Stoneback, 2004). Moreover, some other studies have shown mix results. For example, Phauand Kea (2007) had not found any significant difference between women and men from Hong Kong. Current findings have also shown that moral judgment might be influenced by more than biological (gender) characteristics of an individual. Therefore, by including only gender, it cannot be a powerful antecedent of an individual's ethical/unethical behavior (McCabe, Ingram, \& Dato-on, 2006; Skoe, Cumberland, Eisenberg, Hansen, \& Perry, 2002).

The gender identity theory clarifies this issue by elaborating gender phenomena as a multi-factorial phenomenon (Brettell \& Sargent, 2012; Spence, 1993) which consists of biological gender, instrumental and expressive psychological traits, and gender-role attitudes. According to this theory, an individual gender role is based on their beliefs and attitude which are gender appropriate. Since differences in ethicality may simply be a function of conditioned behaviors, it is more relevant with the existing gender role, rather than genetic or biological predisposition to conclude that men are less ethical than women. It seems necessary for the studies in this field to employ more holistic measurements to examine the real gender role-play. In this study, femininity and masculinity have been suggested to replace dichotomous measurement of gender. Thus, the following hypothesis has been developed;

$\mathrm{H} 2$ : Gender diversity is associated with ethical moral judgment as determined by contractualism, moral equity, relativism, and universalism.

\subsection{Ethnicity}

The traditional distinction between ethnic and ethnicity is considered highly problematic. In some ways, ethnic identity shares aspects of both personal and group identities, but distinct from other group identities, such as racial identity (Mansori et al., 2015; Phinney \& Ong, 2007). Chaudhry et al. (2008) defined ethnicity as "a term, which represents social groups with a shared history, sense of identity, geography and cultural roots. Race, on the other hand, refers to a human population, considered distinct based on physical characteristics alone" (Chaudhry, Neelam, Duddu, \& Husain, 2008, p. 673).

There are few studies, which have tried to investigate the effect of race on ethical behaviors (Conroy \& Emerson, 2004; Emerson \& Conroy, 2004; Emerson, Conroy, \& Stanley, 2007). However, as race is more likely a demographical fact rather than personal characteristics, it seems rational that studies which aim to investigate the relationship between individual characteristics and individual ethical behavior should use ethnic identity instead of race to reach more accurate and deeper results. Thus, to enhance the body of knowledge in this area, this study tests the following hypothesis:

H3: Ethnicity is associated with ethical moral judgment as determined by contractualism, moral equity, relativism, and universalism.

\subsection{Basic Human Values}

Schwartz (1992) introduced the Basic Human Values Theory (BHV) by identifying four basic human values that are recognized across societies. Each one of these four basic values has some dimensions; Openness to change (Stimulation, Hedonism, Self-direction), Self-transcendence (Benevolence, Universalism), Conservation (Security, Conformity, Tradition) and Self-enhancement (Achievement, Power). One's attitude can be influenced by his/her basic values which provide predictive and explanatory power in analyzing attitudes, opinions, and actions (Schwartz, 2007). Openness has been found to be positively related to training proficiency (Barrick \& 
Mount, 1991) and negatively related to salary levels (Seibert \& Kraimer, 2001). Creative people (scientists/artists) have been found to be higher on Openness (Feist, 1998).

However, according to Schwartz (2007), values affect the behavior when activated (Verplanken \& Holland, 2002). In addition, different values are triggered by different situational factors. Goals are important to induce a strong motivation to plan thoroughly. The higher the priority given to a value, it is more likely for the individual to form action plans that can lead to its expression in behavior. Therefore, it can be concluded that basic values are antecedents of individual moral judgment and individuals' moral value can be shaped by their norms and values.

Thus, to keep the parsimony of model, two factors of HBV are included; self-transcendence and self-enhancement; since these two components can have higher influence on individual's moral judgments which are contractualism, moral equity, relativism and universalism. Therefore, the following hypotheses will be tested to investigate the relationship between human basic values and ethical moral judgment;

H4: Self-enhancement is positively associated with ethical moral judgment as determined by contractualism, moral equity, relativism, and universalism.

H5: Self-transcendence is positively associated with ethical moral judgment as determined by contractualism, moral equity, relativism, and universalism.

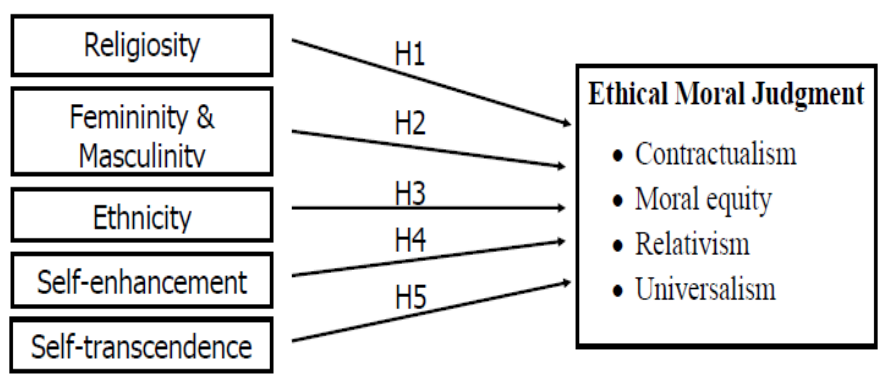

Figure 1. Theoretical model

\section{Methodology}

To test the model of this study, 280 questionnaires were collected from undergraduate business students at five private and public universities by employing self-administration method. The questionnaire has three parts. The first part inquires the participants' idea pertaining to different scenarios which involve some ethical issues.

\subsection{Measurement of Constructs—Ethical Moral Judgment}

To evaluate the ethical judgments of participants, four-item semantic differential scale which is originally developed by Reidenbach and Robin $(1988,1990)$, and later modified by Hartikainen and Torstila, (2004) has been employed. Five job-related ethical/unethical scenarios are presented to the participants and they are asked to evaluate the actions taken on a six-point scale anchored by these opposite word pairs.

To measure Contractualism, two 6-point items are used; "Violates-does not violate an unspoken promise", "Violates-does not violate an unwritten contract" (Reidenbach \& Robin, 1990) and Moral Equity, opposite measurements are used; "Unfair-Fair"; "Unjust-Just"; "Morally wrong-Morally right", and "acceptable-unacceptable". In measuring Relativism, two 6-point items are being employed; "traditionally unacceptable-traditionally acceptable" and "culturally unacceptable-culturally acceptable". However, to measure Universalism only one 6-point items is being employed; "Ethically unacceptable-Ethically acceptable".

\subsection{Religiosity Scale}

One of the most popular and reliable scales to measure religiosity is intrinsic-extrinsic Religious Orientation Scale (ROS). ROS's reliability is acceptable and has been used often in studies related to social science in general and marketing research in particular (De Noble, Galbraith, Singh, \& Stiles, 2007; Delener, 1990, 1994; Essoo \& Dibb, 2004; Mokhlis, 2006). However, some researchers have raised their concern on the direct usage of the scale in marketing research since it is originally developed to measure the religiosity of Christian or Judeo-Christian subjects in North America. Therefore, it may not be a highly reliable tool for a study that covers individuals from a wide range of religious background (Islam, Buddha, Hindu, Christian) and in Asian context 
(Essoo \& Dibb, 2004). Based on previous studies, selecting the accurate scale to measure the religiosity depends upon the cultural and religious background of the population. In this study, the scale developed by Mokllis (2006) is selected since it had been tested in Malaysia and had showed high reliability and validity. This scale consists of 10 questions (6 questions measuring intrapersonal religiosity and 4 questions measuring interpersonal religiosity).

\subsection{Ethnicity Scale}

A uni-dimensional scale cannot capture ethnicity (Phinney \& Goossens, 1996). The most proposed dimensions of ethnic identity are: language, friendship networks, participation in clubs and organizations, endogamy, food preferences, and traditional celebrations (Eriksen, 2002; Kim, Jung, \& Ball-Rokeach, 2007; Laroche, Kim, \& Tomiuk, 1998; Phinney, 1990). To improve the ethnic identity measurement, Phenny and Ong (2007) applied a series of analysis to test the reliability and consistency of the measurement of 'The Multi-group Ethnic Identity Measure' (MIEM-R) (Phinney, 1992 ). In this research, MEIM-R was employed to measure the ethnicity of the participants due to its high level of reliability and validity (Cronbach's alpha of 0.74 for self-direction, 0.76 for exploration, 0.78 for commitment, and for the combined 6-item scale, alpha was 0.81 ).

\subsection{Individual Basic Values Scale}

Schwartz's (1992) Value Survey (SVS) is one of the most reliable surveys in measuring an individual's basic values for years. The usage of this scale in studies conducted in over 65 countries confirmed its uniqueness. With the aim of improving SVS, Schwartz developed a modified version of it in such a way that respondents with different educational and ethnic backgrounds find it easier to understand. The Portrait Values Questionnaire (PVQ) is developed so that the same ten basic value orientations evaluated in SVS are measured in a way that respondents are presented with a survey that is more realistic and simple in terms of rational process compared to the earlier surveys.

Studies that measured values with PVQ had confirmed many predicted associations between value priorities and background, personality, attitude, and behavior variables in samples from diverse countries (Schwartz, 2003). Moreover, the PVQ method had demonstrated adequate psychometric properties for a short scale intended to measure multiple constructs. Studies which were carried out in different countries have provided evidence of PQV's predictive validity, (Schwartz, 2003). In this study, PQV is used to measure the basic values of individuals.

\subsection{Gender Identity Scale}

Gender identity refers to a person's concealed sense of his/her own gender. This is generally described as a person's individual feeling of being a female or a male, consisting primarily of the acceptance of membership into a category of people: men or women. As gender identity is more cognitive process than biological phenomenon, measuring this issue needs an accurate and reliable measurement. The Male-Female Relations Questionnaire (MFRQ) (Spence, Helmreich, \& Sawin, 1980) had been used in many social science (for example, Hock \& Schirtzinger, 2008; McCabe, 2011; Shafiro, Himelein, \& Best, 2003) and ethics studies (for example, McCabe et al., 2006). MFRQ Social Interactions sub-scale consists of 16 questions with five-Likert scale as 1 being strongly disagree to 5 being strongly agree. A high score suggests traditional gender-role attitudes and a low score suggests egalitarian gender-role attitudes. MFRQ has been developed in two versions (Spence et al., 1980); one for female participants and another for male.

\section{Analysis}

After reviewing the returned questionnaires, 251 questionnaires have been included to data analysis, which 47.4 and 52.6 percent of participants are male and female respectively. $76.5 \%$ of participants have learnt the business ethic subject and 23.5 have not attempted this subject. Overall, participants are from six business majors and most of them have accounting, finance and marketing background.

Table 1. Descriptive data

\begin{tabular}{llllll}
\hline Major & $\mathbf{\%}$ & Academic Year & $\mathbf{\%}$ & Pass Ethic course & $\mathbf{\%}$ \\
\hline Accounting & 29.8 & Year 1 & 21.9 & Yes & 76.5 \\
Finance & 19.5 & Year 2 & 57.8 & No & 23.5 \\
Marketing & 19.0 & Year 3 & 14.3 & & Gender \\
Human Resource & 1.6 & Year 4 & 6.0 & Male & 49.0 \\
Management & 11.3 & & & Female & 51.0 \\
Business Admin & 16.4 & & & & \\
Law & 2.4 & & & & \\
\hline
\end{tabular}


The reliability of a measurement instrument is defined in terms of its ability to consistently measure the specified phenomenon (Hair, Wolfinbarger, Money, Samouel, \& Page, 2011; Ho, 2006; Sekaran, 2006). The results of reliability test for the current study are shown in Table 2. Measurement experts recommended using different benchmark ranges for judging adequacy of reliability coefficients, which historically have ranged from .50 to .90 (e.g., DeVellis, 2003; Helms, 2007; Nunnally \& Nunnally, 1970; Streiner, 2003). The results have indicated that the Cronbach's alpha of the all variables are more than .75. Therefore, the results have fulfilled the minimum cut off and can be considered as satisfactory for the purpose of this study (See Table 2).

Table 2. Reliability test

\begin{tabular}{lll}
\hline Variable & Number of Items Comments & Cronbach's Alpha \\
\hline Femininity/Masculinity & 16 & .794 \\
Ethnicity & 6 & .865 \\
Religiosity & 10 & .905 \\
Self-Transcendence & 10 & .834 \\
Self-Enhancement & 7 & .884 \\
\hline
\end{tabular}

Several researchers have used scenarios in their study as research instrument in ethic area (Chonko \& Hunt, 2000; Hunt, Chonko, \& Wood, 1985; Singhapakdi, Vitell, \& Franke, 1999). Five scenarios are adopted by this study to test the relationship between Moral equity, Relativism, Contractualism, Universalism as dependent variable with femininity/masculinity, self-Transcendence and self-Enhancement (indicator of basic human values), religiosity, and ethnicity (independent variables).

This study employs Ordinary Least Squares (OLS) regression to examine the relationship between contractualism perception and the explanatory variables. The following model is estimated:

$$
\text { Contractualism }=\boldsymbol{\beta}_{0+} \boldsymbol{\beta}_{1} F E M \& M E N+\boldsymbol{\beta}_{2} T R A N S+\boldsymbol{\beta}_{3} E N H A N+\boldsymbol{\beta}_{4} R E L I G+\boldsymbol{\beta}_{5} E T H N I+\varepsilon
$$

Where,

FEM \&MEN = femininity and masculinity;

TRANS $=$ self-transcendence;

ENHAN= self-enhancement;

RELIG= religiosity;

$\mathrm{ETHNI}=$ ethnicity.

In addition, self-transcendence and self-enhancement are two indicators for basic human values. The results in Table 3 show that contractualism has a relationship with femininity and masculinity, which are proxies for gender, ( $p$-value is 0.029 ), self-transcendence ( $p$-value is 0.000 ), and Ethnicity ( $p$-value is 0.046 ), but this perception does not have a relationship with the other two independent variables which are religiosity ( $p$-value is 0.151 ), and self-enhancement ( $p$-value is 0.909). Therefore; contractualism is affected by the level of femininity/masculinity, self-Transcendence, and ethnicity.

To test the second hypothesis of the study, the following model has been tested:

$$
\text { Moral equity }=\boldsymbol{\beta}_{0}+\boldsymbol{\beta}_{1} F E M \& M E N+\boldsymbol{\beta}_{2} T R A N S+\boldsymbol{\beta}_{3} E N H A N+\boldsymbol{\beta}_{4} R E L I G+\boldsymbol{\beta}_{5} E T H N I+\varepsilon
$$

Where,

FEM\&MEN = femininity and masculinity;

TRANS $=$ self-transcendence;

ENHAN= self-enhancement;

RELIG= religiosity;

$\mathrm{ETHNI}=$ ethnicity.

Results have revealed that moral equity perception has a significant relationship with self-transcends ( $p$-value $<.05$ ), self-enhancement ( $p$-value <.05), and religiosity ( $p$-value is 0.044). However, there is lack of a relationship between moral equity perception with ethnicity ( $p$-value $>.05)$ and femininity/masculinity 
( $p$-value $>.05)$. Therefore; the results show that moral equity perception is affected by the level of human basic values (two indicators) and religiosity.

Hypothesis 3 is tested using the following linear model;

$$
\text { Universalism }=\boldsymbol{\beta}_{0}+\boldsymbol{\beta}_{1} F E M \& M E N+\boldsymbol{\beta}_{2} \text { TRANS }+\boldsymbol{\beta}_{3} E N H A N+\boldsymbol{\beta}_{4} R E L I G+\boldsymbol{\beta}_{5} E T H N I+\varepsilon
$$

Where,

FEM\&MEN = femininity and masculinity;

TRANS $=$ selftranscendence;

ENHAN= self-enhancement;

RELIG= religiosity;

$\mathrm{ETHNI}=$ ethnicity.

The results in Table 3 show that universalism has a significant relationship with self-Transcendence $(p$-value $<.05)$, self-enhancement ( $p$-value $<.05)$, and religiosity $(p$-value $<.05)$, but does not have any significant relationship with the other two independent variables; femininity/masculinity ( $p$-value $>.05)$ and ethnicity ( $p$-value>.05). Thus, people's universalism is affected by the level of their basic human values and religiosity.

To test the fourth hypothesis, the following model is estimated:

$$
\text { Relativism }=\boldsymbol{\beta}_{0}+\boldsymbol{\beta}_{1} \text { FEM\&MEN }+\boldsymbol{\beta}_{2} \text { TRANS }+\boldsymbol{\beta}_{3} \text { ENHAN }+\boldsymbol{\beta}_{4} \text { RELIG }+\boldsymbol{\beta}_{5} \text { ETHNI }+\varepsilon
$$

Where,

FEM\&MEN = femininity and masculinity;

TRANS $=$ self-Transcendence;

ENHAN $=$ self-Enhancement;

RELIG= religiosity;

$\mathrm{ETHNI}=$ ethnicity.

This study's results show that relativism perception has a significant relationship with femininity/masculinity ( $p$-value $<.05)$, self-transcends ( $p$-value $<.05)$, and ethnicity $(p$-value $<.05)$. Where else, it has no relationship with self-enhancement ( $p$-value $>.05)$ or religiosity ( $p$-value $>.05)$. Based on the results, Relativism's perception is impacted by factors such as femininity/masculinity, self-transcends, and ethnicity.

\section{Discussion}

\subsection{Religiosity}

The analysis shows that religiosity has a negative relationship with universalisim and moral equity. In other word, individuals with high levels of religiosity seem to have lower negative feeling toward infringing the universal values of moral judgment and moral equality. However, religiosity has not shown any significant relationship with contractualism, or relativism.

\subsection{Ethnicity}

Results indicate that ethnicity has direct effect on contractualism and relativism. It means individuals with higher levels of ethnicity consider the described actions as unfair and unjust. They also consider that the actions taken are not acceptable by the norms in their traditions and culture. Despite of that, ethnicity does not show any significant relationship with moral judgment and universalism.

\subsection{Gender Identity}

The current results indicate that gender identity has a direct relationship with contractualism and relativism but no significant relationship with universalism and moral equity. It means that individuals with higher levels of femininity (low level of masculinity) consider taken actions against their traditions and culture. In addition, they also consider the actions taken infringe the unwritten/unspoken contract. In contrast, individuals with high level of masculinity have higher levels of acceptance of infringing the moral judgment codes.

\subsection{Self-transcendence}

Current results show that the self-transcendence has direct relationship with contractualism, universalism, moral equality, and relativism. These results indicate that individuals with higher levels of self-transcendence have high negative perception toward the actions taken and consider them as morally wrong, unfair, and unjust. 
Moreover, this group considers the actions taken as unethical, traditionally, and culturally unacceptable behaviors. According to BHV, self-transcendence consists of two human characteristics which are benevolence; preserving and enhancing the welfare of those with whom one is in frequent personal contact (the 'in-group'); and universalism which encompasses understanding, appreciation, tolerance, and protection for the welfare of all people and for nature (Bilsky \& Schwartz, 1994, p. 196). These two characteristics encourage individuals to be more conscious toward any activity which can be considered as inequity or unacceptable by society.

\subsection{Self-enhancement}

HBV describes self-enhancement as composite of two dimensions (achievement; personal success through demonstrating competence according social standards, power; social status and prestige, control or dominance over individuals and resources) (Bilsky \& Schwartz, 1994, p. 196). Results show that self-enhancement has a negative and significant impact on contractualism, universalism, and moral equity. However, self-enhancement does not have a significant effect on relativism. These findings show that individuals with higher level of self-enhancement have lower negative perception and attitude toward infringing the unwritten/unspoken contracts. These individuals do not really think that the actions taken are unethical, unfair, and unjust to the customers in the given scenarios. The findings of this study show that individuals with high ambitions have higher tendency to violate the moral judgment factors in order to achieve their personal goals.

\section{Conclusion}

Overall, the findings of this study have revealed that personal traits and psychological factors have meaningful associations with individual ethic judgment. Findings reveal that individuals with higher levels of self-transcendence, femininity, and ethnicity also have high negative attitude toward infringing moral judgment. In contrast individuals with higher levels of self-enhancement have a high tendency to commit the behavior which is against moral judgment factors.

Therefore, it seems necessary that employers focus on appropriate procedures (e.g., pre-employment tests) in order to evaluate their team members' potential unethical behavior in various situations by identifying their personal traits. Furthermore, it would be advisable for companies to employ individuals with high level of self-transcendence, femininity and ethnicity for the positions that are evolved in activities which require high sensitivity and may involve unclear moral values.

This study has tried to test the robust model by testing the impact of individual's triads on ethical judgment. However, the results of regression models show that there are another variable that can be included in the model to improve the model's $\mathrm{R}^{2}$. Moreover, to understand other cultural factors (for example; Hofstede cultural dimensions) it is suggested that further studies include samples from different countries in order to conduct a comparative study between different nations.

Table 3. Results of regression models

\begin{tabular}{|c|c|c|c|c|c|c|c|c|c|c|c|c|}
\hline \multirow[t]{3}{*}{ Variable } & \multicolumn{12}{|c|}{ Dependent variables } \\
\hline & \multicolumn{3}{|c|}{ Contractualism } & \multicolumn{3}{|c|}{ Moral equity } & \multicolumn{3}{|c|}{ Universalism } & \multicolumn{3}{|c|}{ Relativism } \\
\hline & $\mathrm{B}$ & $\mathrm{t}$ & $P$ & $\mathrm{~B}$ & $\mathrm{t}$ & $P$ & $\mathrm{~B}$ & $\mathrm{t}$ & $P$ & $\mathrm{~B}$ & $\mathrm{t}$ & $P$ \\
\hline Intercept & 4.452 & 9.313 & .000 & 3.245 & 8.033 & .000 & 3.528 & 9.460 & .000 & 3.684 & 8.850 & .000 \\
\hline Femininity/Masculinity & .215 & 2.198 & .029 & .054 & .662 & .509 & .049 & .651 & .516 & .228 & 2.689 & .008 \\
\hline Self-Transcendence & -.375 & -5.329 & .000 & -.389 & -6.513 & .000 & -.452 & -8.253 & .000 & -.234 & -3.780 & .000 \\
\hline Self-Enhancement & -.006 & -.114 & .909 & .148 & 3.600 & .000 & .166 & 4.396 & .000 & -.022 & -.525 & .600 \\
\hline Religiosity & .109 & 1.440 & .151 & .128 & 2.023 & .044 & .119 & 2.052 & .041 & .093 & 1.416 & .158 \\
\hline Ethnicity & -.198 & -2.010 & .046 & -.093 & -1.118 & .265 & -.096 & -1.256 & .211 & -.231 & -2.671 & .008 \\
\hline $\mathrm{R}^{2}$ & .209 & & & .207 & & & .293 & & & .179 & & \\
\hline $\operatorname{Adj} R^{2}$ & .191 & & & .189 & & & .277 & & & .160 & & \\
\hline$F$-value & 11.468 & & & 11.639 & & & 18.403 & & & 9.570 & & \\
\hline$P$-value of F & $.000^{\mathrm{a}}$ & & & $.000^{\mathrm{a}}$ & & & $.000^{\mathrm{a}}$ & & & $.000^{\mathrm{a}}$ & & \\
\hline
\end{tabular}

\section{References}

Ahmed, F. U. (2000). Systems and National Level Experiences for Protecting Traditional Knowledge, Innovations and Protections: Experience of Bangladesh.

Ajzen, I. (2002, January, 2006). Constructing a TpB questionnaire: Conceptual and methodological considerations. Retrieved from http://www.people.umass.edu/aizen/pdf/tpb.measurement.pdf 
Arslan, M. (2001). The Work Ethic Values of Protestant British, Catholic Irish and Muslim Turkish Managers. Journal of Business Ethics, 31(4), 321-339. http://dx.doi.org/10.1023/A:1010787528465

Barnett, T., Bass, K., \& Brown, G. (1996). Religiosity, Ethical Ideology, and Intentions to Report a Peer's Wrongdoing. Journal of Business Ethics, 15(11), 1161-1174. http://dx.doi.org/10.1007/BF00412815

Barnett, T., Bass, K., Brown, G., \& Hebert, F. (1998). Ethical Ideology and the Ethical Judgments of Marketing Professionals. Journal of Business Ethics, 17(7), 715-723. http://dx.doi.org/10.1023/A:1005736404300

Baumhart, R. (1961). Problems in Review. survey on business ethics.

Beck, L., \& Ajzen, I. (1991). Predicting Dishonest Actions using the Theory of Planned Behavior. Journal of Research in Personality, 25, 285-301. http://dx.doi.org/10.1016/0092-6566(91)90021-H

Beu, D. S., Buckley, M. R., \& Harvey, M. G. (2003). Ethical Decision-Making: A Multidimensional Construct. Business Ethics: A European Review, 12(1), 88-106. http://dx.doi.org/10.1111/1467-8608.00308

Bilsky, W., \& Schwartz, S. H. (1994). Values and personality. European Journal of Personality, 8(3), 163-181. http://dx.doi.org/10.1002/per.2410080303

Bobek, D. D., \& Hatfield, R. C. (2003). An Investigation of the Theory of Planned Behavior and the Role of Moral Obligation in Tax Compliance. Behavioral Research in Accounting, 15. http://dx.doi.org/10.2308/bria.2003.15.1.13

Brettell, C. B., \& Sargent, C. F. (2012). Gender in cross-cultural perspective. Pearson Higher Ed.

Brockett, A., \& Rezaee, Z. (2012). Corporate Sustainability: Integrating Performance and Reporting. Wiley.

Buchan, H. F. (2005). Ethical Decision Making in the Public Accounting Profession: An Extension of Ajzen's Theory of Planned Behavior. Journal of Business Ethics, 61, 165-181. http://dx.doi.org/10.1007/s10551-005-0277-2

Cardy, R., \& Selvarajan, T. (2006). Assessing Ethical Behavior: The Impact of Outcomes on Judgment Bias. Journal of Managerial Psychology. http://dx.doi.org/10.1108/02683940610643215

Chang, M. K. (1998). Predicting Unethical Behavior: A Comparison of the Theory of Reasoned Action and the Theory of Planned Behavior. Journal of Business Ethics, 17(16), 1825-1834. http://dx.doi.org/10.1023/A:1005721401993

Chaudhry, I., Neelam, K., Duddu, V., \& Husain, N. (2008). Ethnicity and psychopharmacology. Journal of Psychopharmacology, 22(6), 673-680. http://dx.doi.org/10.1177/0269881107082105

Chonko, L. B., \& Hunt, S. D. (2000). Ethics and Marketing Management: A Retrospective and Prospective Commentary. Journal of Business Research, 50(3), 235-244. http://dx.doi.org/10.1016/S0148-2963(00)00175-2

Conner, M., \& Armitage, C. J. (1998). Extending the Theory of Planned Behavior: A Review and Avenues for

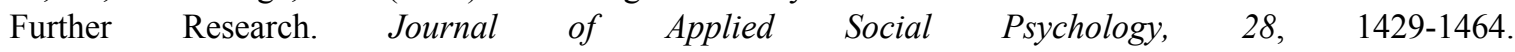
http://dx.doi.org/10.1111/j.1559-1816.1998.tb01685.x

Conroy, S. J., \& Emerson, T. N. (2004). Business Ethics and Religion: Religiosity as a Predictor of Ethical Awareness among Students. Journal of Business Ethics, 50(4), 383-396. http://dx.doi.org/10.1023/B:BUSI.0000025040.41263.09

Craft, J. L. (2013). A review of the empirical ethical decision-making literature: 2004-2011. Journal of Business Ethics, 117(2), 221-259. http://dx.doi.org/10.1007/s10551-012-1518-9

De Noble, A., Galbraith, C. S., Singh, G., \& Stiles, C. H. (2007). Market justice, religious orientation, and entrepreneurial attitudes An empirical study. Journal of Enterprising Communities: People and Places in the Global Economy, 1(2), 121-134. http://dx.doi.org/10.1108/17506200710752548

Delener, N. (1990). The effect of religious factors on perceived risk in durable goods purchase decisions. Journal of Consumer Marketing, 7(3), 27-37. http://dx.doi.org/10.1108/EUM0000000002580

Delener, N. (1994). Religious contrasts in consumer decision behaviour patterns: Their dimensions and marketing implications. European Journal of Marketing, 28(5), 36-53. http://dx.doi.org/10.1108/03090569410062023

DeVellis, R. F. (2003). Scale development: Theory and applications. Sage Publications, Inc. 
Douglas, P., Davidson, R., \& Schwartz, B. (2001). The Effect of Organizational Culture and Ethical Orientation on Accountants. Journal of Business Ethics, 34(2). http://dx.doi.org/10.1023/A:1012261900281

Emerson, T. N., \& Conroy, S. J. (2004). Have Ethical Attitudes Changed? An Intertemporal Comparison of the Ethical Perceptions of College Students in 1985 and 2001. Journal of Business Ethics, 50(2), 167-176. http://dx.doi.org/10.1023/B:BUSI.0000022126.48574.6e

Emerson, T. N., Conroy, S. J., \& Stanley, C. W. (2007). Ethical Attitudes of Accountants: Recent Evidence from a Practitioners' Survey. Journal of Business Ethics, 71, 73-87. http://dx.doi.org/10.1007/s10551-006-9125-2

Eriksen, T. H. (2002). Ethnicity and nationalism. London: Pluto Press.

Essoo, N., \& Dibb, S. (2004). Religious Influences on Shopping Behaviour: An Exploratory Study. Journal of Marketing Management, 20, 683-712. http://dx.doi.org/10.1362/0267257041838728

Hair, J. F. J., Wolfinbarger, M., Money, A. H., Samouel, P., \& Page, M. J. (2011). Essentials of business research methods. ME Sharpe Inc.

Hart, D. (2005). The Development of Moral Identity, Nebraska Symposium on Motivation. Paper presented at the 51 .

Hartikainen, O., \& Torstila, S. (2004). Job-related ethical judgment in the finance profession. Journal of Applied Finance, 14, 62-76.

Helms, J. E. (2007). Some better practices for measuring racial and ethnic identity constructs. Journal of Counseling Psychology, 52, 235-246. http://dx.doi.org/10.1037/0022-0167.54.3.235

Ho, R. (2006). Handbook of univariate and multivariate data analysis and interpretation with SPSS. CRC Press. http://dx.doi.org/10.1201/9781420011111

Hock, E., \& Schirtzinger, M. B. (2008). Maternal separation anxiety: Its developmental course and relation to maternal mental health. Child Development, 63(1), 93-102. http://dx.doi.org/10.2307/1130904

Hood, R. W., Spilka, B., Hunsberger, B., \& Gorsuch, R. (1996). The Psychology of Religion: An Empirical Approach. New York: Guildford Press.

Hunt, S. D., Chonko, L. B., \& Wood, V. R. (1985). Organizational commitment and marketing. The Journal of Marketing, 112-126. http://dx.doi.org/10.2307/1251181

Ian, P., \& Kea., G. (2007). Attitudes of University Students towardBusiness Ethics: A Cross-National Investigation of Australia, Singapore and Hong Kong. Journal of Business Ethics, 72, 61-75. http://dx.doi.org/10.1007/s10551-006-9156-8

Kallgren, C. A., Reno, R. R., \& Cialdini, R. B. (2000). A Focus Theory of Normative Conduct: When Norms Do and Do Not Affect Behavior. Personality and Social Psychology Bulletin, 26(8), 1002-1012. http://dx.doi.org/10.1177/01461672002610009

Khavari, K. A., \& Harmon, T. M. (1982). The Relationship between the Degree of Professed Religious Belief and Use of Drugs. International Journal of the Addictions, 17, 847-857. http://dx.doi.org/10.3109/10826088209056331

Kim, Y.-C., Jung, J.-Y., \& Ball-Rokeach, S. J. (2007). Ethnicity, place, and communication technology ; Effects of ethnicity on multi-dimensional internet connectedness. Information Technology \& People, 20(3), 282-303. http://dx.doi.org/10.1108/09593840710822877

Kurpis, L. V., Beqiri, M. S., \& Helgeson, J. G. (2008). The Effects of Commitment to Moral Self-improvement and Religiosity on Ethics of Business Students. Journal of Business Ethics, 80, 447-463. http://dx.doi.org/10.1007/s10551-007-9430-4

Laroche, M., Kim, C., \& Tomiuk, M. A. (1998). Italian ethnic identity and its relative impact on the consumption of convenience and traditional foods. Journal of Consumer Marketing, 15(2), 125-151. http://dx.doi.org/10.1108/07363769810210340

Lee, K., McCann, D., \& Ching, M. (2003). Christ and Business Culture: A Study of Christian Executives in Hong Kong. Journal of Business Ethics, 43(2/1), 103-110. http://dx.doi.org/10.1023/A:1022967300183

Lewis, L., \& Unerman, J. (1999). Ethical Relativitism: A Reason for Differences in Corporate Social Reporting? Critical Perspective on Accounting, 10, 521-547. http://dx.doi.org/10.1006/cpac.1998.0280 
Lindfelt, L., \& To"rnroos, J. (2006). Ethics and Value Creation in Business Research: Comparing Two $\begin{array}{llll}\text { Approaches. European Journal of Marketing, } & \text { 40(3/4), }\end{array}$ http://dx.doi.org/10.1108/03090560610648084

Mansori, S., Sambasivan, M., \& Md-Sidin, S. (2015). Acceptance of novel products: the role of religiosity, ethnicity and values. Marketing Intelligence \& Planning, 33(1). http://dx.doi.org/10.1108/MIP-03-2013-0050

Mason, E. S., \& Mudrack, P. E. (1996). Gender and Ethical Orientation: A Test of Gender and Occupational Socialization Theories. Journal of Business Ethics, 15(6), 599-604. http://dx.doi.org/10.1007/BF00411793

McCabe, A. C. (2011). Spectators' relationship women's professional basketball: Is it more than sex. North American Journal of Psychology, 13(1), 107-122.

McCabe, A. C., Ingram, R., \& Dato-on, M. C. (2006). The Business of Ethics and Gender. Journal of Business Ethics, 64(2), 101-116. http://dx.doi.org/10.1007/s10551-005-3327-x

Mokhlis, S. (2006). The Effect of religiosity on shopping orientation: An exploratory study in Malaysia. The Journal of American Academy of Business, Cambridge, 9(1), 64-74.

Moore, R. S., \& Radloff, S. E. (1996). Attitudes Towards Business Ethics Held By South African Students. Journal of Business Ethics, 15(8), 863-870. http://dx.doi.org/10.1007/BF00381854

Nunnally, J. C., \& Nunnally. (1970). Introduction to psychological measurement. McGraw-Hill.

O'Fallon, M. J., \& Butterfield, K. D. (2005). A Review of the Empirical Ethical Decision Making Literature: 1996-2003. Journal of Business Ethics, 59(4), 375-413. http://dx.doi.org/10.1007/s10551-005-2929-7

Oxford Advanced Learner's Dictionary. (2005). Oxford: Oxford University Press.

Oxford Advanced Learner's Dictionary. (2012). Oxford: Oxford University Press.

Parboteeah, K. P., Hoegl, M., \& John, B. C. (2008). Ethics and Religion: An EmpiricalTest of a $\begin{array}{lllll}\text { Multidimensional Model. Journal of Business Ethics, } & \text { 80, 387-398. }\end{array}$ http://dx.doi.org/10.1007/s10551-007-9439-8

Passow, H. J., Mayhew, M. J., Finelli, C. J., Harding, T. S., \& Carpenter, D. D. (2006). Factors Influencing Engineering Students' Decisions to Cheat by Type of Assessment. Research in Higher Education, 47(6), 643-684. http://dx.doi.org/10.1007/s11162-006-9010-y

Phau, I., \& Kea., G. (2007). Attitudes of University Students toward Business Ethics: A Cross-National Investigation of Australia, Singapore and Hong Kong. Journal of Business Ethics, 72, 61-75. http://dx.doi.org/10.1007/s10551-006-9156-8

Phinney, J. S. (1990). Ethnic Identity in Adolescents and Adults: Review of Research. Psychological Bulletin, 10(3), 499-514. http://dx.doi.org/10.1037/0033-2909.108.3.499

Phinney, J. S. (1992). The Multigroup Ethnic Identity Measure: A new scale for use with diverse groups. Journal of Adolescent Research, 7, 156-176. http://dx.doi.org/10.1177/074355489272003

Phinney, J. S., \& Goossens, L. (1996). Identity development in context. Journal of Adolescence, 19, 401-403. http://dx.doi.org/10.1006/jado.1996.0038

Phinney, J. S., \& Ong, A. D. (2007). Conceptualization and Measurement of Ethnic Identity: Current Status and Future Directions. Journal of Counseling Psychology, 54(3), 271-281. http://dx.doi.org/10.1037/0022-0167.54.3.271

Reidenbach, R. E., \& Robin, D. P. (1988). Some initial steps toward improving the measurement of ethical evaluations of marketing activities. Journal of Business Ethics, 7(11), 871-879. http://dx.doi.org/10.1007/BF00383050

Reidenbach, R. E., \& Robin, D. P. (1990). Toward the development of a multidimensional scale for improving evaluations of business ethics. Journal of Business Ethics, 9(8), 639-653. http://dx.doi.org/10.1007/BF00383391

Roxas, M. L., \& Stoneback, J. Y. (2004). The Importance of Gender Across Cultures in Ethical Decision Making. Journal of Business Ethics, 50(2), 149-165. http://dx.doi.org/10.1023/B:BUSI.0000022127.51047.ef 
Schwartz, S. H. (1992). Universals in the content and structure of values:Theoretical advances and empirical tests in 20 countries. In M. P. Zanna (Ed.), Advances in experimental social psychology (Vol. 25, pp. 1-65). New York: Academic Press.

Schwartz, S. H. (2003). A proposal for measuring value orientations across nations. Questionnaire Package of the European Social Survey, 259-290.

Schwartz, S. H. (2007). Universalism values and the inclusiveness of our moral universe. Journal Of Cross-Cultural Psychology, 38(6), 711-728. http://dx.doi.org/10.1177/0022022107308992

Schwartz, S. H., \& Tessler, R. C. (1972). A Test of a Model for Reducing Measured Attitude-Behavior Discrepancies. Journal of Personality and Social Psychology, 24(2), 225-236. http://dx.doi.org/10.1037/h0033365

Sekaran, U. (2006). Research methods for business: A skill building approach. Wiley, India.

Shafiro, M. V., Himelein, M. J., \& Best, D. L. (2003). Ukrainian and US American Females Differences in Individualism/Collectivism and Gender Attitudes. Journal Of Cross-Cultural Psychology, 34(3), 297-303. http://dx.doi.org/10.1177/0022022103034003004

Sheppard, B. H., Hartwick, J., \& Warshaw, P. R. (1988). The Theory of Reasoned Action: A Meta-Analysis of Past Research with Recommendations for Modifications and Future Research. Journal of Consumer Research, 15(3), 325-343. http://dx.doi.org/10.1086/209170

Sims, R., \& Gegez, A. (2004). Attitudes Towards Business Ethics: A Five Nation Comparative Study. Journal of Business Ethics, 50(3), 253-265. http://dx.doi.org/10.1023/B:BUSI.0000024708.07201.2d

Singhapakdi, A., Vitell, S. J., \& Franke, G. R. (1999). Antecedents, consequences, and mediating effects of perceived moral intensity and personal moral philosophies. Journal of the Academy of Marketing Science, 27(1), 19-36. http://dx.doi.org/10.1177/0092070399271002

Skoe, E. E. A., Cumberland, A., Eisenberg, N., Hansen, K., \& Perry, J. (2002). The Influences of Sex and Gender-Role Identity on Moral Cognition and Prosocial Personality Traits. Sex Roles, 46(9/10), 295-309. http://dx.doi.org/10.1023/A:1020224512888

Small, M. (1992). Attitudes towards Business Ethics held by Western Australian Students: A Comparative Study. Journal of Business Ethics, 11(10), 745-752. http://dx.doi.org/10.1007/BF00872306

Spence, J. T. (1993). Gender-related Traits and Gender Ideology: Evidence for a Multifactorial Theory. Journal of Personality and Social Psychology, 64(4), 624-635. http://dx.doi.org/10.1037/0022-3514.64.4.624

Spence, J. T., Helmreich, R. L., \& Sawin, L. L. (1980). The Male-Female Relations Questionnaire: A self-report inventory of sex role behaviors and preferences and its relationships to masculine and feminine personality traits, sex role attitudes, and other measures: American Psycholog. Ass., Journal Suppl. Abstract Service.

Streiner, D. L. (2003). Starting at the beginning: an introduction to coefficient alpha and internal consistency. Journal of Personality Assessment, 80(1), 99-103. http://dx.doi.org/10.1207/S15327752JPA8001_18

Ugoji, K., Dando, N., \& Moir, L. (2007). Does Business Ethics Pay?, Revisited: The Value of Ethics Training. Institute of Business Ethics.

Verplanken, B., \& Holland, R. W. (2002). Motivated decision making: Effects of activation and self-centrality of values on choices and behavior. Journal of Personality and Social Psychology, 82, 434-447. http://dx.doi.org/10.1037/0022-3514.82.3.434

Vitell, S. J., \& Paolillo, J. (2003). Consumer Ethics: The Role of Religiosity. Journal of Business Ethics, 46(2), 151-162. http://dx.doi.org/10.1023/A:1025081005272

Walker, A. G., Smither, J. W., \& DeBode, J. (2012). The effects of religiosity on ethical judgments. Journal of Business Ethics, 106(4), 437-452. http://dx.doi.org/10.1007/s10551-011-1009-4

Weaver, G. R., \& Agle, B. R. (2002). Religiosity and Ethical Behavior in Organizations: A Symbolic Interactionist Perspective. Academy of Management Review, 27(1), 77-97.

Weeks, W., Moore, R. S., McKinney, J., \& Longenecker, J. (1999). The Effects of Gender and Career Stage on Ethical Judgment. Journal of Business Ethics, 20(4), 301-313. http://dx.doi.org/10.1023/A:1005955501120 


\section{Copyrights}

Copyright for this article is retained by the author(s), with first publication rights granted to the journal.

This is an open-access article distributed under the terms and conditions of the Creative Commons Attribution license (http://creativecommons.org/licenses/by/3.0/). 